\title{
The role of extra-cellular adenosine receptors in modulating pain progression during osteoarthritis (OA): A systematic review of the literature
}

\author{
Weaver $\mathrm{NC}^{1 *}$, Habusta $\mathrm{SF}^{1}$ and Raymond $\mathrm{RM}^{2}$ \\ ${ }^{1}$ Department of Orthopedics, Lake Erie College of Osteopathic Medicine, USA \\ ${ }^{2}$ Department of Physiology, Lake Erie College of Osteopathic Medicine, USA
}

\begin{abstract}
Osteoarthritis: OA continues to be one of the most commonly treated diseases in the United States, resulting in significant financial burden to both patients and healthcare systems. OA is a form of degenerative joint pain caused by progressive destruction within the joints. With the progression of OA, the cartilage, which acts to cushion joints, begins to be eroded, resulting in the destructive rubbing of bone-on-bone. The wear and tear leads to inflammation and pain of the joints. Despite years of clinical experience in treating OA, there remains to be a treatment that adequately alleviates pain, other than complete knee replacement.

Inflammation and pain: Adenosine is an adenine nucleoside that has been reported to be elevated during exercise and inflammation. Adenosine release at inflamed sites contributes to the erythema and resulting increased temperature at the site of inflammation. Experimentally, it was shown that at low adenosine concentrations, inflammation is exaggerated, leading to dramatic swelling, pain, increased blood flow, etc. Data has clearly shown the adenosine's anti-inflammatory actions results from activation of the extracellular adenosine $\mathrm{A} 2 \mathrm{~A}$ receptors on the vascular endothelium. These data suggest that adenosine, released at inflamed sites, diminishes the swelling that is so prominent at inflamed sites. Recent evidence has suggested that OA is an inflammatory/metabolic disease. Adenosine has been reported to have a bi-modal effect: at low concentrations adenosine acts via specific extracellular adenosine receptors to alleviate pain by acting as an anti-inflammatory agent, however, at relatively higher concentrations, different adenosine receptors are activated and induce pain by becoming cytotoxic. Several reports have suggested that adenosine and/or adenosine deaminase may be used as an early pre-clinical marker of arthritis.
\end{abstract}

Hypothesis: During the early onset of OA, critical amounts of adenosine are released which act as anti-inflammatory agents. At these low concentrations of adenosine, the anti-inflammatory response is mediated via activation of the extracellular adenosine A2A receptor. Adenosine A1A receptor is also activated, which primarily decreases nerve conduction and metabolism, thereby acting as an anti-nociceptive mediator. Progression of AO leads to downregulation of A1A and A2A and activation of $\mathrm{A} 2 \mathrm{~B}$ receptors, which progressively increases the pain/inflammation and destruction of joints. Adenosine concentrations or extracellular adenosine receptor activation/deactivation may be early markers for assessing the progressive stage of OA.

\section{Introduction}

In 2013 it was estimated that nearly $11.9 \%$ of the U.S. population suffered from symptomatic OA [1-4], requiring various surgical interventions $[5,6]$. Despite the cost to society [7-11] and the potential morbidity and mortality which can result from such invasive surgical procedures, roughly half of all adults diagnosed with knee OA have undergone a total knee replacement during their lifetime [12]. According to the American Academy of Orthopedic Surgery, the standard of care for non-surgical management of progressive OA involve lifestyle changes, which includes weight loss, low impact exercises [13-15], and changes in diet [16]. Patient management also includes oral medical treatments and intra-articular injections of potent anti-inflammatory drugs $[10,17]$ and physical therapy [18]. Although these treatments can be beneficial [10] in treating the symptoms of pain associated with the early stages of $\mathrm{OA}$, the quality of these treatment modalities is largely unpredictable and can develop adverse side effects [19]. These treatments have been shown to be less effective during the late worsening stages of $\mathrm{OA}$ [20]. To date, there are no currently known treatments which block the progression of OA, nor the pain associated with this disease [21].

\section{Discussion}

Conventional wisdom argues that $\mathrm{OA}$ is a weight-bearing disease resulting in progressive and cumulative destruction of articular cartilage which leads to pain $[17,20,22]$. This progressive and destructive process consists of early cartilage fibrillation with developments to fissuring, ulceration, subchondral sclerosis, joint-space narrowing, and eventual full-thickness loss of hyaline cartilage [4,8,23-25].

Clinical and basic science research suggests that $\mathrm{OA}$ is an inflammatory disease much like rheumatoid arthritis [26-28]. There is growing evidence that OA may share several signs and symptoms relating to the metabolic syndrome [29,30], i.e., obesity, hypertension, type 2 diabetes mellitus, and hyperlipidemia [31]. This potential mechanism is substantiated by the fact that there is a high prevalence

*Correspondence to: Raymond RM, Department of Physiology, Lake Erie College of Osteopathic Medicine, USA, Tel: 8148668453; Fax: 8148668411; E-mail: rraymond@lecom.edu

Received: September 15, 2018; Accepted: September 25, 2018; Published: September 27, 2018 
of OA in non-weight bearing joints such as the shoulders and hands [26,32-34]. These clinical data indicate that the etiologies associated with non-weight bearing OA may be multifactorial [12,22,27,33,35,36]. Further evidence demonstrated that the incidence of $\mathrm{OA}$ in weight bearing joints does not necessarily increase as weight increases [12], although there is evidence to suggest that knee arthritis may correlate with weight [17]. Evidence has suggested that the severity of pain correlates with the progression of OA, despite the fact that the articular hyaline cartilage, which degenerates over time, is devoid of both neural innervation and vascular supply $[20,37,38]$.

Research has provided evidence that adenosine concentrations, during the early stages of inflammation, $[20,39,40]$ can act as both an analgesic, by combining with the extracellular A1 adenosine receptor, [41] and as an anti-inflammatory response with binding to the A2A adenosine receptor $[42,43]$. Adenosine has four main extracellular receptors: $\mathrm{A} 1 \mathrm{~A}, \mathrm{~A} 2 \mathrm{~A}, \mathrm{~A} 2 \mathrm{~B}$ and $\mathrm{A} 3$, all of which are G-coupled proteins and each with different functions $[24,34,39,44]$. The actions of adenosine concentration within specialized tissues and cells have been shown to be related to the interactions of these specific adenosine receptors $[39,45]$. Experiments have shown that at low concentrations, adenosine primarily binds to the high sensitivity A1 and A2A receptors, resulting in analgesia via decreased nociceptor nerve conduction [46] and anti-inflammation by the production of antiinflammatory mediators $[39,43]$. Studies utilizing A1 receptor deficient mice recently showed that $\mathrm{A} 1$ receptors play a critical role in osteoclast development from monocytic precursors and bone resorption $[47,48]$ In contrast to $\mathrm{A} 1$ adenosine receptors, $\mathrm{A} 2 \mathrm{~A}$ receptors inhibit osteoclast differentiation and function $[42,49]$ and $\mathrm{A} 2 \mathrm{~A}$ receptor stimulation has been shown to inhibit wear particle-induced osteolysis, a form of inflammatory bone destruction resulting from particulates shed from joint prostheses [43]. However, adenosine concentrations have a bimodal effect: at low concentrations adenosine acts as a direct analgesic [41], and anti-inflammatory mediator [39], and at high concentrations, adenosine directly induces pain $[20,45,50,51]$ with pro-inflammatory cytotoxic effects [32,39]. These divergent effects of adenosine have been proposed to be related to the modulation of specific extracellular adenosine receptors $[30,39,52-54]$. In an unrelated but similar clinical situation, patients suffering from cardiac electrical pathologies, such as supraventricular tachycardia or atrial fibrillation, can be treated by giving an intra-venous bolus injection of adenosine to convert the arrhythmia to sinus rhythm [12,34]. Once administered, patients feel a crushing angina-like chest pain despite the fact that many of these patients do not have a history of coronary artery disease $[11,34,55]$. These effects are primarily related to the stimulation of different types of extracellular cytotoxic adenosine receptors (i.e., A2B) [56]. During $\mathrm{OA}$, as well as rheumatoid arthritis, recent reports have shown that both adenosine and adenosine deaminase concentrations were increased in serum and knee synovial fluid $[39,44]$. Adenosine has been reported to induce analgesia during acute inflammation [20,39,41,57]. However, with chronic inflammation, adenosine may induce hyperalgesia $[20,51,57]$. Adenosine's metabolic pathway with interactions of specific intracellular and extracellular adenosine receptors may be important for the maintenance of healthy articular cartilage metabolism, as well as being an important analgesic mediator linked to the early phases of OA [24,39,51].

In chronic inflammatory disorders such as rheumatoid arthritis, adenosine and adenosine deaminase were reported to be markedly increased [47]. At increased adenosine concentrations, adenosine was reported to bind to the low sensitivity $\mathrm{A} 2 \mathrm{~B}$ receptor, resulting in hyperalgesia [20,51]. Binding of adenosine to the low sensitivity A2B receptor inhibits adenosine binding to the $\mathrm{A} 1$ and $\mathrm{A} 2 \mathrm{~A}$ receptors $[8,45]$, thereby removing their analgesic effects.

Abo-Salem, et al. [58] also recognized the hyperalgesic effects of A2B receptor activation. They completed experiments that provided evidence that caffeine, a known analgesic, accomplishes its analgesic effects through binding and blocking the $\mathrm{A} 2 \mathrm{~B}$ receptor. The A2B receptor activation has also been shown to be cytotoxic at increased adenosine concentrations $[50,58]$, and would therefore be a source of an inflammatory process [59]. Adenosine released at inflamed sites diminishes both the swelling (tumor) leukocyte recruitment and adhesion [60]. Adenosine-activated A2A receptors, has long been known to be a potent vasodilator [61]. These vascular effects of adenosine (A2A) are the basis for pharmacologic stress testing [62]. Adenosine receptor stimulation diminishes neutrophil adhesion to the endothelium by inhibiting both selectin- and integrin-mediated adhesive events [63]. ATP binding to A3 receptor initiates downregulation or inhibition of A3 receptors, decreasing leukocyte recruitment to sites of bacterial infection [64]. The use of adenosine as an anti-inflammatory agent has remained more of a challenge due to the myriad of other effects adenosine has through stimulation of the A2A and A2B receptor [16,20,30,37,41,49,52-54,65,66]. Interestingly, it is now clear that low-dose methotrexate, the anchor drug for the treatment of rheumatoid arthritis, mediates its anti-inflammatory effects via promotion of adenosine release at inflamed sites [67].

Methotrexate is actively transported into the cell where it is polyglutamated; MTX polyglutamate is a potent inhibitor of AMP deaminase. Accumulation of AICAR, an intermediate metabolite in de novo purine biosynthesis, leads to enhanced release of adenine nucleotides which are released into the extracellular space and converted to adenosine. MTXglu, methotrexate polyglutamates; DHFglu, dihydrofolate polyglutamates; AICAR, aminoimidazole carboxamidoribonucleotide; FAICAR, formyl AICAR; RFC1, reverse folate carrier 1; ADA, adenosine deaminase; $\mathrm{AK}$, adenosine kinase; NTPDase, nucleoside triphosphate phosphohydrolase; ecto- $5^{\prime} \mathrm{NT}$, ecto-5'nucleotidase (Figure 1).

Non-specific adenosine receptor antagonists, theophylline and caffeine reversed the effect of methotrexate on hind-paw swelling and ankylosis in experimental adjuvant arthritis [67].

Pulsed electromagnetic field technology [68] and scintigraphy [50] have been shown to upregulate the A2A adenosine receptor, known to cause vasodilation [69]. Increased blood flow would not only supply nutrients and oxygen to the tissue but may also increase the delivery of other mediators which serve clinically to aid in tissue repair. Adenosine deaminase (ADA) irreversibly degrades adenosine into inosine, hypoxanthine and xanthine and acts as a homeostatic mechanism to maintain adenosine within the normal physiologic range [69]. Elevated plasma ADA may therefore be an early marker for joint inflammation $[8,10,65]$ and implicate the need for further investigation.

Enohumah and Imarengiaye [20] have broken down the most basic of anatomic structures responsible for pain which include free nerve endings i.e., nociceptors. Four different types of nerves have been found to be responsible for nociception in joints [70]. These innervate the joint capsule, subchondral bone, periosteum, ligaments, and menisci [20]. The four different types of nociceptor nerves have been termed types I through IV, or A-alpha, A-beta, A-delta, and C [70]. Various structures within the knee, shown to elicit pain during OA, include the fat pads, ligaments, and synovium [20]. All of these studies have confirmed that articular cartilage was not a source of pain. Articular cartilage 
receives its' nutrition from the synovial fluid in which it is bathed, and is avascular, and lacks the necessary innervations which would be responsible for pain [20]. Essentially, all of the other structures found in the intra-articular space have been identified to have at least types III and IV sensory nerves [20,71]. The fact that intra-articular injection of local anesthetic [72] or removal of intraarticular structures in total knee arthroplasty often result in significant analgesia which provides a rational hypothesis that pain, during the progression of $\mathrm{OA}$, is mainly associated with intraarticular structures [20,50,71,73,74]. Activated subchondral bone [8] nociceptors may be the reason why patient do not receive similar pain reduction following total knee arthroplasty or intraarticular injections which contain a local anesthetic [75].

During the early stages of $\mathrm{OA}$, slight increases in adenosine concentrations ( anti-nociceptive (A1) and anti-inflammatory (A2A) agonist (Figure 2) $[54,60,64,70]$. As $\mathrm{OA}$ progresses to the late stage, adenosine concentration increases substantially to activate the low sensitivity A2B receptor. $\mathrm{A} 2 \mathrm{~B}$ activation inhibits the $\mathrm{A} 1 \mathrm{~A}$ receptor thereby resulting in pain (Figure 3) $[16,30,45,53,66,76]$.

\section{The Metabolic Effects of Methotrexate}

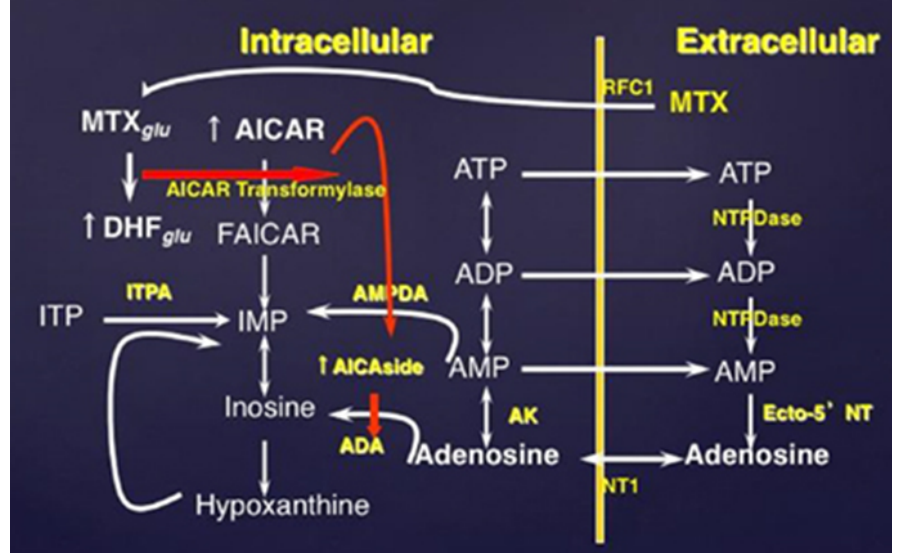

Figure 1. The effect of methotrexate on adenosine release

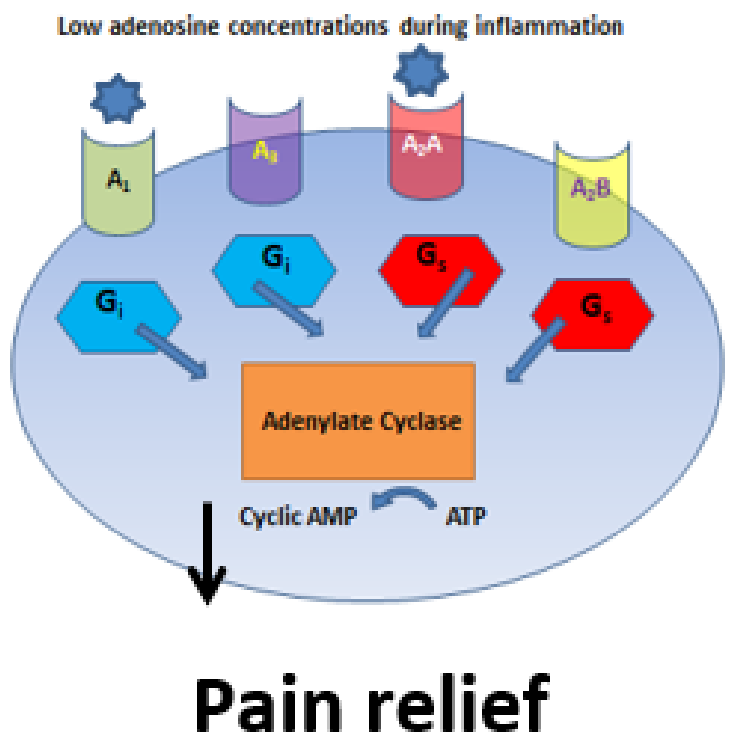

Figure 2. Extracellular adenosine receptor; A1, A3, A2A, A2B. G-protein inhibitory Gi or stimulatory Gs proteins.

\section{High adenosine concentrations during progressive $O A$}

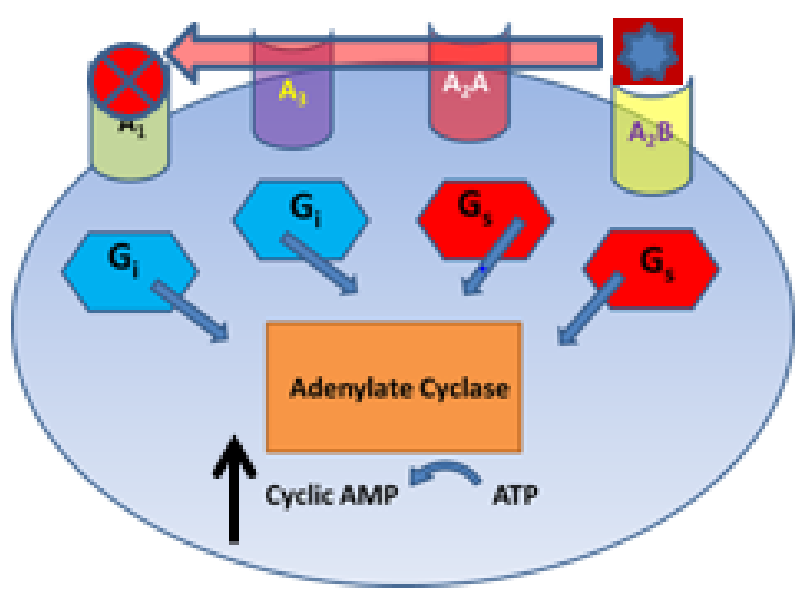

\section{Induced pain}

Figure 3. Extracellular adenosine receptor; A1, A3, A2A, A2B. G-protein inhibitory Gi or stimulatory Gs proteins. A1 receptor blockade

\section{Conclusion}

Further investigations are required to determine the role of extracellular adenosine receptors acting as an anti-inflammatory agent during the early stages of OA; the anatomical structure(s) responsible for producing adenosine; and the activation/inactivation of specific extracellular receptors responsible for severe chronic pain. Data from these studies may provide basic clinical treatments for the relief of pain associated with OA. Our hypothesis is during the early phase of OA pain is alleviated in part by adenosine binding the A1A and $\mathrm{A} 2 \mathrm{~A}$ receptors, which are both low sensitivities.

\section{References}

1. Racine J, Aaron RK (2013) Pathogenesis and epidemiology of osteoarthritis. R I Med J 96: 19-22. [Crossref]

2. Losina E, Thornhill TS, Rome BN, Wright J, Katz JN (2012) The Dramatic Increase in Total Knee Replacement Rates in the United States Cannot Be Fully Explained by Growth in Population Size and the Obesity Epidemic. J Bone Joint Surg Am 94: 201-207.

3. Losina E, Walensky RP, Kessler CL, Emrani PS, Reichmann WM, et al. (2009) Costeffectiveness of total knee arthroplasty in the United States: patient risk and hospital volume. Arch Intern Med 169: 1113-1121. [Crossref]

4. Martel-Pelletier J, Mineau F, Jolicoeur FC, Cloutier JM, Pelletier JP (1998) In vitro effects of diacerhein and rhein on interleukin 1 and tumor necrosis factor-alpha systems in human osteoarthritic synovium and chondrocytes. J Rheumatol 25: 753-762.

5. Kurtz S, Ong K, Lau E, Mowat F, Halpern M (2007) Projections of primary and revision hip and knee arthroplasty in the United States from 2005 to 2030. J Bone Joint Surg Am 89: 780-785. [Crossref]

6. Liu J, Elkassabany N, Poultsides L, Nelson CL, Memtsoudis SG (2015) Staging Bilateral Total Knee Arthroplasty During the Same Hospitalization: The Impact of Timing. J Arthroplasty 30: 1172-1176. [Crossref]

7. Abbadie C, Besson JM, Calvino B (1994) C-Fos expression in the spinal cord and painrelated symptoms induced by chronic arthritis in the rat are prevented by pretreatment with freund adjuvant. $J$ Neurosci 14: 58-65.

8. Burr DB (2004) The importance of subchondral bone in the progression of osteoarthritis J Rheumatol Suppl 70: 77-80. [Crossref]

9. Chen A, Gupte C, Akhtar K, Smith P, Cobb J (2012) The Global Economic Cost of Osteoarthritis: How the UK Compares. Arthritis 2012: 698709. [Crossref] 
10. Dinesh B, Bejarano T, Novo M (2011) Current interventions in the management of knee osteoarthritis. Journal of Pharmacy and Bioallied Sciences 4: 24-36.

11. Weinstein AM, Rome BN, Reichmann WM, Collins JE, Burbine SA, et al. (2013) Estimating the burden of total knee replacement in the United States. J Bone Joint Surg Am 95: 385-392. [Crossref]

12. Saville PD, Dickson J (1968) Age and weight in osteoarthritis of the hip. Arthritis Rheum 11: 635-644. [Crossref]

13. Fitzgerald GK (2005) Therapeutic exercise for knee osteoarthritis: considering factors that may influence outcome. Europa Medicophysica 36: 163-171.

14. Kosek E, Roos EM, Ageberg E, Nilsdotter A (2013) Increased pain sensitivity but normal function of exercise induced analgesia in hip and knee osteoarthritis - treatment effects of neuromuscular exercise and total joint replacement. Osteoarthritis Cartilage 21: $1299-1307$.

15. Richmond J. Hunter D, Irrgang J, Jones MH, Levy B, et al. (2009) Treatment of osteoarthritis of the knee (Nonarthroplasty). J Am Acad Orthop Surg 17: 591-600.

16. Ham J, Evans BA (2012) An emerging role for adenosine and its receptors in bone homeostasis. Front Endocrinol (Lausanne) 3: 113. [Crossref]

17. Manek NJ, Hart D, Spector TD, MacGregor AJ (2003) The association of body mass index and osteoarthritis of the knee joint: An examination of genetic and environmental influences. Arthritis Rheum 48: 1024-1029.

18. Borea PA, Baraldi PG (1998) Sixth international symposium on adenosine and adenine nucleotides: New frontier in the third millennium. Drug Develp Research 45: 85.

19. Mendieta EDM, Ibanez TC, Jaeger JU, Hernan GB, Mola EM (2006) Clinical and ultrasonographic findings related to knee pain in osteoarthritis. Osteoarthritis Cartilage 14: 540-544.

20. Enohumah KO, Imarengiay CO (2006) Pain in osteoarthritis: A review of literature. Southern African Journal of Anaesthesia and Analgesia 13: 24-24.

21. Helal B (1965) The pain in primary osteoarthritis of the knee. Its causes and treatment by osteotomy. Postgrad Med J 41: 172-181. [Crossref]

22. Griffin TM, Guilak F (2005) The role of mechanical loading in the onset and progression of osteoarthritis. Exerc Sport Sci Rev 33: 195-200. [Crossref]

23. Kalichman L, Hernandez-Molina G (2010) Hand Osteoarthritis: An epidemiological perspective. Semin Arthritis Rheum 39: 465-476.

24. Li G, Yin J, Gao J, Cheng S, Pavlos NJ, et al. (2013) Subchondral bone in osteoarthritis: insight into risk factors and microstructural changes. Arthritis Res Ther 15: 223.

25. Lo GH, McAlindon TE, Niu J, Zhang Y, Beals C, et al. (2009) Bone marrow lesions and joint effusion are strongly and independently associated with weight-bearing pain in knee osteoarthritis: data from the osteoarthritis initiative. Osteoarthritis Cartilage 17: $1562-1569$.

26. Cicuttini FM, Baker JR, Spector TD (1996) The association of obesity with osteoarthritis of the hand and knee in women: a twin study. J Rheumatol 23: 1221-1226. [Crossref]

27. Goldring MB, Otero M (2011) Inflammation in osteoarthritis. Current Opinion in Rheumatology 20: 451-456.

28. Zhang RX, Ren K, Dubner R (2013) Osteoarthritis pain mechanisms: basic studies in animal models. Osteoarthritis Cartilage 21: 1308-1315.

29. Sellam J, Berenbaum F (2013) Is osteoarthritis a metabolic disease? Joint Bone Spine 80: 568-573. [Crossref]

30. Hu X, Adebiyi MG, Luo J, Sun K, Le T, et al. (2016) Sustained elevated adenosine via ADORA2B promotes chronic pain through neuro-immune interaction. Cell Rep 16: 106-119.

31. Courties A, Sellam J, Berenbaum F (2017) Metabolic syndrome-associated osteoarthritis. Curr Opin Rheumatol 29: 214-222.

32. Pottie P, Presle N, Terlain B, Netter P, Mainard D, et al. (2006) Obesity and osteoarthritis: more complex than predicted. Ann Rheum Dis 65: 1403-1405. [Crossref]

33. Sellam J, Berenbaum F (2013) Is osteoarthritis a metabolic disease? Joint Bone Spine 80: 568-573. [Crossref]

34. Yusuf E, Nelissen R, loan-Facsinay A, Stojanovic-Susulic V, DeGroot J, et al. (2010) Association between weight or Body Mass Index and hand osteoarthritis: a systematic review. Ann Rheum Dis 69: 761-765.

35. Neogi T (2013) The epidemiology and impact of pain in osteoarthritis. Osteoarthritis Cartilage 21: 1145-1153.
36. Wojtys EM, Beaman DN, Glover RA, Janda D (1990) Innervation of the human knee joint by substance-P fibers. Arthroscopy 6: 254-263. [Crossref]

37. Dray A (1995) Inflammatory mediators of pain. Br J Anaesth 75: 125-131. [Crossref]

38. Demir G, Borman P, Ayhan F, Ozgun T, Kaygiziz F, et al. (2014) Serum adenosine deaminase level is high but not related with disease activity parameters in patients with rheumatoid arthritis. Open Rheumatol J 8: 24-28.

39. Antonioli L, Colucci R, La Motta C, Tuccori M, Awwad O, et al. (2012) Adenosine deaminase in the modulation of immune system and its potential as a novel target for treatment of inflammatory Disorders. Curr Drug Targets 13; 842-862.

40. De Lange-Brokaar, loan-Facsinay A, van Osc GJVM, Zuurmond AM, Schoones J, et al. (2012) Synovial inflammation, immune cells and their cytokines in osteoarthritis: a review. Osteoarthritis Cartilage 20: 1484-1499.

41. Hayashida M, Fukuda K, Fukunaga A (2005) Clinical application of adenosine and ATP for pain control. J Anesth 19: 225-235. [Crossref]

42. https://www.livestrong.com/

43. Khoa ND, Montesinos MD, Reiss AB, Delano D, Awadallah N, et al. (2001) Inflammatory cytokines regulate function and expression of adenosine $\mathrm{A} 2 \mathrm{~A}$ receptors in human monocytic THP-1 Cells. J Immunol 167: 4026-4032.

44. Demir G, Borman P, Ayhan F, Ozgun T, Kaygisiz F, et al. (2014) Serum adenosine deaminase level is high but not related with disease activity parameters in patients with rheumatoid arthritis. Open Rheumatol J 8: 24-28.

45. Abo-Salem OM, Hayallah AM, Bilkei-Gorzo A, Filipek B, Zimmer A, et al. (2004) Antinociceptive Effects of Novel A2B Adenosine Receptor Antagonists. J Pharmacol Exp Ther 308: 58-66.

46. Spychala J (2000) Tumor-promoting functions of adenosine. Pharmacology \& Therapeutics 87: 161-173.

47. Haskó G, Cronstein B (2013) Regulation of inflammation by adenosine. Front Immunol 4: 85. [Crossref]

48. Kara FM, Chitu V, Sloane J, Axelrod M, Fredholm BB, et al. (2010) Adenosine A1 receptors (A1Rs) play a critical role in osteoclast formation and function. FASEB J 24: 2325-2333. [Crossref]

49. Deaglio S, Dwyer KM, Gao W, Friedman D, Usheva A, et al. (2007) Adenosine generation catalyzed by $\mathrm{CD} 39$ and $\mathrm{CD} 73$ expressed on regulatory $\mathrm{T}$ cells mediates immune suppression. $J$ Exp Med 204: 1257-1265. [Crossref]

50. Dye SF, Chew MH (1994) The use of scintigraphy to detect increased osseous metabolic activity about the knee. Instr Course Lect 43: 453-469.

51. Tesch AM, MacDonald MH, Kollias-Baker C, Benton HP (2004) Endogenously produced adenosine regulates articular cartilage matrix homeostasis: enzymatic depletion of adenosine stimulates matrix degradation. Osteoarthritis Cartilage 12 349-359.

52. Little JW, Ford A, Symons-Liguori AM, Chen Z, Janes K, et al. (2015) Endogenous adenosine A3 receptor activation selectively alleviates persistent pain states. Brain 138: 28-35.

53. Sawynok J (2016) Adenosine receptor targets for pain. Neuroscience 338: 1-18 [Crossref]

54. Sawynok J (1998) Adenosine receptor activation and nociception. Eur J Pharmacol 347: 1-11. [Crossref]

55. Sylvén C, Beermann B, Jonzon B, Brandt R (1986) Angina pectoris-like pain provoked by intravenous adenosine in healthy volunteers. Br Med J (Clin Res Ed) 293: 227-230. [Crossref]

56. Wilbur SL, Marchlinski FE (1997) Adenosine as an antiarrhythmic agent. Am J Cardiol 79: 30-37. [Crossref]

57. Alvarez FJ, Fyffe RE (2000) Nociceptors for the 21st century. Curr Rev Pain 4: 451458. [Crossref]

58. Zhang W, Jones A, Doherty M (2004) Does paracetamol acetaminophen reduce the pain of osteoarthritis? A meta-analysis of randomized control trials. Ann Rheum Dis 63: 901-907.

59. Mistry D, Chambers MG, Mason RM (2006) The role of adenosine in chondrocyte death in murine osteoarthritis and in a murine chondrocyte cell line. Osteoarthritis Cartilage 14: 486-495.

60. Cronstein BN, Levin RI, Philips M, Hirschhorn R, Abramson SB, et al. (1992) Neutrophil adherence to endothelium is enhanced via adenosine A1 receptors and inhibited via adenosine A2 receptors. J Immunol 148: 2201-2206. [Crossref]

61. Manjunath S, Sakhare PM (2009) Adenosine and adenosine receptors: Newer therapeutic perspective. Indian Journal of Pharmacology. 41: 97-105. 
62. McGuinness ME, Talbert RL (1994) Pharmacologic stress testing: experience with dipyridamole, adenosine, and dobutamine. Am J Hosp Pharm 51: 328-346. [Crossref]

63. Fredholm BB (2007) Adenosine, an endogenous distress signal, modulates tissue damage and repair. Cell Death Differ 14: 1315-1323.

64. Zhang N, Huifang Dong DY, Chen Q, Dimitrova DI, Rogers TJ, et al. (2006) Adenosine A2a receptors induce heterologous desensitization of chemokine receptors. Blood 108: 38-44.

65. Antonioli L, Colucci R, La Motta C, Tuccori M, Awwad O, et al. (2021) Adenosine deaminase in the modulation of immune system and its potential as a novel target for treatment of inflammatory disorders. Curr Drug Targets 13: 842-862.

66. Dai Y, Zhang W, Wen J, Zhang Y, Kellems RE, et al. (2011) A2B adenosine receptormediated induction of IL-6 promotes CKD. J Am Soc Nephrol 22: 890-901. [Crossref]

67. Montesinos MC, Yap JC, Desai A, Posadas I, McCrary CT, et al. (2000) Reversal of the anti-inflammatory effects of methotrexate by the nonselective adenosine receptor antagonists theophylline and caffeine: Evidence that the anti-inflammatory effects of methotrexate are mediated via multiple adenosine receptors in rat adjuvant arthritis. Arth and Rheum 43: 656-663.

68. Varani K, Mattei MD, Vincenzi F, Gessi S, Merighi S, et al. (2008) Characterization of adenosine receptors in bovine chondrocytes and fibroblast-like synoviocytes exposed to low frequency low energy pulsed electromagnetic fields. Osteoarthritis Cartilage 16: 292-304.
69. Layland J, Carrick D, Lee M, Colin B (2014) Adenosine: Physiology, Pharmacology, and Clinical Applications. JACC 7: 581-591.

70. Lawson SN (2002) Phenotype and function of somatic primary afferent nociceptive neurones with C-, Adelta- or Aalpha/beta-fibres. Exp Physiol 87: 239-244. [Crossref]

71. McDougall JJ (2006) Pain and OA. J Musculoskelet Neuronal Interact 6: 385-386. [Crossref]

72. Creamer P, Hunt M, Dieppe P (1996) Pain mechanisms in osteoarthritis of the knee: effect of intraarticular anesthetic. J Rheumatol 23: 1031-1036. [Crossref]

73. Felson DT, Chaisson CE, Hill CL, Totterman SM, Gale ME, et al. (2001) The association of bone marrow lesions with pain in knee osteoarthritis. Ann Intern Med 134: 541-549. [Crossref]

74. Creamer P, Hunt M, Dieppe P (1996) Pain mechanisms in osteoarthritis of the knee: effect of intraarticular anesthetic. J Rheumatol 23: 1031-1036. [Crossref]

75. Dieppe PA, Lohmander LS (2005) Pathogenesis and management of pain in osteoarthritis. Lancet 365: 965-973. [Crossref]

76. Gonçalves FQ, Pires J, Pliassova A, Beleza R, Lemos C, et al. (2015) Adenosine A2b receptors control A1 receptor-mediated inhibition of synaptic transmission in the mouse hippocampus. Eur J Neurosci 41: 878-888.

Copyright: $(2018$ Weaver NC. This is an open-access article distributed under the terms of the Creative Commons Attribution License, which permits unrestricted use, distribution, and reproduction in any medium, provided the original author and source are credited. 